\title{
Efficacy of Hemocoagulase as a Topical Hemostatic Agent After Dental Extractions: A Systematic Review
}

\author{
Gauri Gupta ${ }^{1}$, Muthusekhar M.R. ${ }^{1}$, Santhosh P. Kumar ${ }^{2}$ \\ 1. Oral and Maxillofacial Surgery, Saveetha Dental College, Saveetha University, Chennai 2. Oral and \\ Maxillofacial Surgery, Saveetha Dental College and Hospital, Saveetha University, Chennai, IND
}

$\square$ Corresponding author: Santhosh P. Kumar, santhoshsurgeon@gmail.com

Disclosures can be found in Additional Information at the end of the article

\section{Abstract}

Extraction is one of the more common oral surgical procedures carried out in routine dental practice, and postextraction bleeding is a recognized, frequently encountered complication. It causes distress, agony, and discomfort to the patient. The aim of this systematic review was to analyze the existing literature and determine the efficacy of topical hemocoagulase as a hemostatic agent and its ability to reduce postoperative complications in comparison to routine saline pressure pack after the extraction of teeth. Information was collected from an electronic database (PubMed), and a manual search was also done in Oral Surgery, Oral Medicine, Oral Pathology, Oral Radiology; International Journal of Oral and Maxillofacial Surgery; and the British Journal of Oral and Maxillofacial Surgery. Only those articles which met the inclusion criteria were selected. All studies and articles that compared topical hemocoagulase with saline pressure pack in patients requiring extraction of teeth were selected for review. Literature abstracts and full-text articles were analysed in this review. A total of four articles were included in this systematic review. All were randomized clinical trials that evaluated the clinical outcomes of topical hemocoagulase compared with saline pressure packs in extraction socket sites. A significant difference was present between the hemocoagulase group and control group (saline pressure pack) in relation to bleeding stoppage time, pain, swelling, wound healing, and other postoperative complications. Topical hemocoagulase is significantly effective in reducing bleeding, pain, and swelling after extraction of tooth when compared to saline pressure packs. It also acts as a promoter of wound healing.

Received 03/22/2018 Review began $03 / 23 / 2018$ Review ended 03/24/2018 Published 03/30/2018

\section{(C) Copyright 2018}

Gupta et al. This is an open access article distributed under the terms of the Creative Commons Attribution License CC-BY 3.0., which permits unrestricted use, distribution, and reproduction in any medium, provided the original author and source are credited.
Categories: Pain Management, Miscellaneous, Other

Keywords: hemostasis, hemocoagulase, bleeding, wound healing, extraction, oral surgery, local hemostatic agent, saline pressure packs

\section{Introduction And Background}

Bleeding during oral surgical procedures can cause distress, agony, and discomfort to the patient. It also distracts the oral surgeon from operating, leading to frustration and time consumption. Tooth removal or extraction is one of the more common invasive oral surgical procedures carried out in routine dental practice, and postextraction bleeding is a recognized, frequently encountered complication in dental practice [1]. Postextraction bleeding is defined as "evidence of bleeding beyond the pressure pack" [2]. There is a wide array of techniques suggested for the management of postextraction bleeding, both in healthy and medically compromised patients [3-5]. Interventions for managing postextraction bleeding can be broadly categorized into local and systemic interventions [6]. Local intervention includes common saline pressure pack, sutures, acrylic surgical splints, and local hemostatic agents [7]. Local 
hemostatic agents used in oral surgery are classified into passive and active hemostatic agents. They include oxidized cellulose, resorbable gelatin sponge, collagen sponge, polysaccharide hemospheres, thrombin, cyanoacrylate glue, fibrin glue adhesive, local antifibrinolytic solutions such as tranexamic acid mouthwash, bone wax, ostene, calcium alginate, chitosanbased dressings, polysaccharide-based hemostats, tannic acid, and hemocoagulase [8-10]. If necessary, systemic hemostatic agents can be used for achieving hemostasis.

Hemocoagulase, a fractional isolate of poisonous Bothrops jararaca, is an enzyme complex. It accelerates the formation of fibrin monomers and hastens fibrin clot formation [11]. The application of hemocoagulase after extraction produces reduced bleeding stoppage time, postoperative pain, and swelling after the extraction of teeth [12]. Hemocoagulase is contraindicated in venous and arterial thrombosis, and in patients with a tendency for intravascular coagulation. It can be applied topically or administered through intramuscular or intravenous routes depending upon the condition to be treated.

A systematic review based on the highest clinical evidence will indicate the benefits of hemocoagulase in the management of postoperative bleeding after dental extractions [3]. Hence, the aim of this systematic review was to compare the efficacy of hemocoagulase as a topical hemostatic agent with routine saline pressure pack after tooth extraction.

\section{Review}

\section{Structured question}

Is local application of hemocoagulase a simple and effective way of reducing postoperative complications as compared to saline pressure pack after extraction of teeth?

\section{Population, intervention, comparison, and outcome analysis}

Our population, intervention, comparison, and outcome (PICO) analysis was as follows:

P: Patients requiring more than one extraction such as full mouth extraction for dentures or extractions for orthodontic treatment

I: Topical hemocoagulase solution

C: Saline pressure pack

O: Postoperative bleeding, pain, and swelling

\section{Inclusion criteria}

Clinical trials, comparison studies, and studies only in English were included in this review.

\section{Types of participants/samples}

Patients requiring more than one extraction (orthodontic intervention necessitating bilateral removal, full mouth extraction for dentures, bilateral impacted lower third molar teeth)

\section{Types of intervention}

1. Topical hemocoagulase

2. Saline pressure pack 


\section{Outcome measures}

Postoperative bleeding, pain, and swelling, wound healing

\section{Exclusion criteria}

Animal studies and literature in other languages were excluded from the review process.

\section{Literature search}

Information was collected from an electronic database (PubMed). A search was also done in Oral Surgery, Oral Medicine, Oral Pathology, Oral Radiology; International Journal of Oral and Maxillofacial Surgery; British Journal of Oral and Maxillofacial Surgery to date.

\section{Search methodology}

The search methodology was a combination of Medical Subject Headings terms and suitable keywords based on PICO formulated for the review. The terms used were dental extractions, hemocoagulase, botropase, saline pressure packs, hemostasis, postoperative pain, and swelling.

\section{Selection of studies}

The review process consisted of two phases. In the first phase, the title and abstracts of the articles obtained through the PubMed search were examined for relevance. The full text of relevant articles was obtained and accessed. In the second phase, relevant articles were isolated based on inclusion and exclusion criteria for further data extraction and statistical analysis. All studies that compared topical hemocoagulase with saline pressure pack in patients requiring extraction of teeth were selected for review.

\section{Data extraction and quality evaluation}

Data extraction for general characteristics of all included studies and variables of outcomes were done. All articles identified as suitable were read in their entirety, considered for inclusion, and summarized based on general characteristics such as sample size, study groups, treatment, methods of evaluation, results, statistical analysis, and inference.

Variables of interest were postoperative bleeding stoppage time, where the time was measured from application of the material into the socket or surgical site up to the complete stoppage of bleeding by using a stopwatch, pain, and swelling. Levels of evidence of included studies and risk of bias were done for all the studies. Outcomes assessment and risk of bias for the included studies were assessed based on the consort criteria. The study was assessed to have a "high risk" of bias if it did not record a "yes" in three or more of the four main categories; "moderate" if two out of four categories did not record a "yes"; and "low" if randomization, assessor blinding, and completeness of follow-up was considered adequate.

The electronic database search identified 21 articles based on the query. After reading titles and abstracts, 18 studies were excluded as they were irrelevant for the review. After examination of full texts, the remaining three studies were included in the review. After a manual search of articles, one relevant article was added to the review process (Figure 1). 


\section{Cureus}

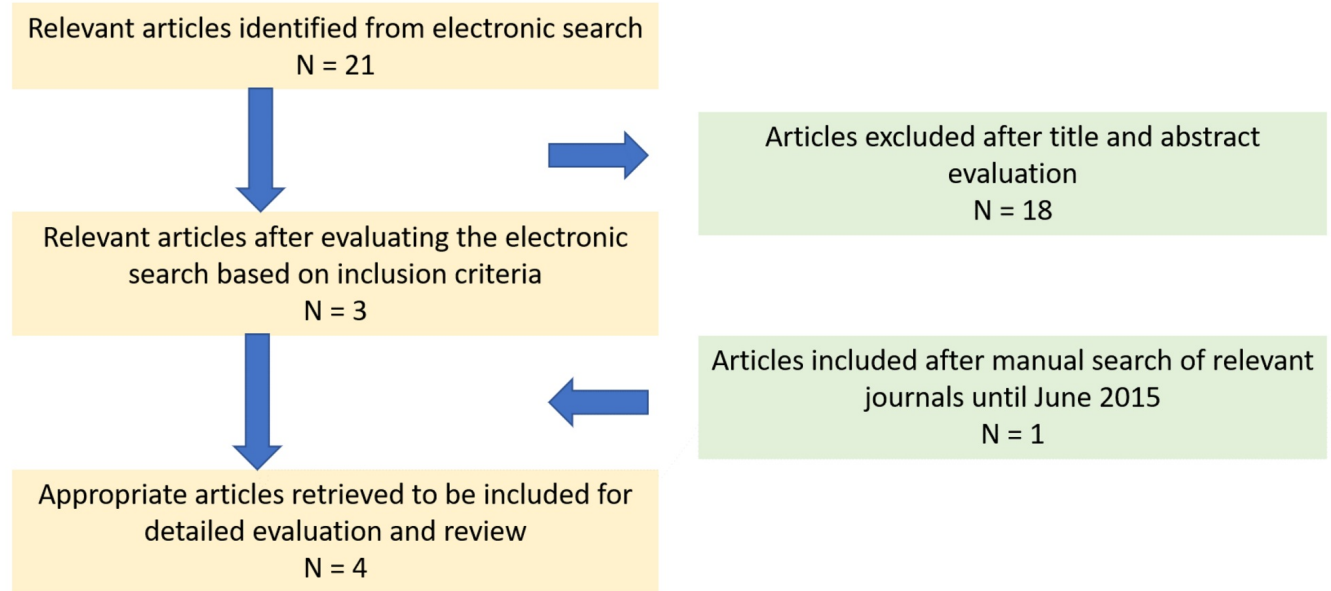

\section{FIGURE 1: PRISMA flowchart for selection of studies.}

Abbreviations: PRISMA, Preferred Reporting Items

Finally, four articles were included for review in the present study, and their characteristics are described in Table 1 and Table 2.

S.

NO

AND
JOURNAL

Aslam et al.

The Journal

of

1 Contemporary

Dental

Practice.

2013 [20]
SAMPLE

SIZE

$20(40$
surgical
sites)
$[20]$

$25(50$

Majumder et

al.,

International

2 Journal of

Clinical

Medicine.

2014 [21] surgical

sites) -

group 1

$50(100$

surgical

sites) -

group 2
STUDY

LOCATION

\section{INTERVENTION}

Forty extractions for

orthodontic reasons were

done in 20 patients

bilaterally. Two groups of 20

samples each: Group A

(Site A): $1 \mathrm{cc}$ of

hemocoagulase was locally

applied in the socket

following extraction. Group

B (Site B) (control group):

Placebo, no hemocoagulase

was applied after extraction

of tooth [20]

Fifty simple extractions (for complete dentures or for orthodontic reasons) were done. Fifty bilateral impactions (100 extractions) were done. Site A:

Hemocoagulase was used topically by local irrigation to control hemorrhage. Site B (control): No drug was used

\section{METHODS OF EVALUATION}

Bleeding stoppage time was recorded using a stopwatch to record the time from placement of solution up to complete formation of clot. Pain at six hours: Postoperatively, one information chart in the form of a visual analogue scale was given to each patient for evaluating postoperative pain [20]

Bleeding stoppage time was recorded using a stopwatch to record the time from placement of solution up to complete formation of clot. Pain at six hours: Postoperatively, one information chart in the form of a visual analogue scale was given to each patient for evaluating postoperative pain. Swelling reference points: Lateral corner of the eye to angle of the mandible and tragus of the ear to the corner of the mouth. Postoperatively, 


\section{Cureus}

\begin{tabular}{|c|c|c|c|c|c|}
\hline & \multicolumn{3}{|c|}{ [21] } & $\begin{array}{l}\text { to control the hemorrhage } \\
\text { [21] }\end{array}$ & $\begin{array}{l}\text { study parameters were recorded after one } \\
\text { hour, two hours, three hours, six hours, } \\
\text { and nine hours [21] }\end{array}$ \\
\hline 3 & $\begin{array}{l}\text { Joshi et al., } \\
\text { Annals of } \\
\text { Maxillofacial } \\
\text { Surgery. } 2014 \\
\text { [22] }\end{array}$ & $\begin{array}{l}200 \text { (400 } \\
\text { surgical } \\
\text { sites) } \\
\text { [22] }\end{array}$ & $\begin{array}{l}\text { Bharati } \\
\text { Vidyapeeth } \\
\text { University } \\
\text { India [22] }\end{array}$ & $\begin{array}{l}\text { A total of } 200 \text { patients who } \\
\text { underwent symmetrical } \\
\text { bilateral orthodontic } \\
\text { extractions were analyzed } \\
\text { for bleeding stoppage time. } \\
\text { After extraction of teeth on } \\
\text { one side, hemocoagulase } \\
\text { (1U) was applied, and on } \\
\text { the other side, pompom } \\
\text { impregnated with placebo (1 } \\
\text { mL normal saline [NS]) was } \\
\text { applied [22] }\end{array}$ & $\begin{array}{l}\text { Mean bleeding stoppage time was } \\
\text { evaluated using a stopwatch [22] }\end{array}$ \\
\hline 4 & $\begin{array}{l}\text { Solanki et al., } \\
\text { International } \\
\text { Journal } \\
\text { Research in } \\
\text { Medical } \\
\text { Sciences. } \\
2015 \text { [23] }\end{array}$ & $\begin{array}{l}100 \text { (200 } \\
\text { surgical } \\
\text { sites) } \\
{[23]}\end{array}$ & $\begin{array}{l}\text { PDU } \\
\text { University } \\
\text { India [23] }\end{array}$ & $\begin{array}{l}\text { Extraction of grossly } \\
\text { decayed or non-restorable } \\
\text { teeth, or due to severe } \\
\text { periodontitis in } 100 \text { patients } \\
\text { (200 sites) were included in } \\
\text { the study. At the first site } \\
\text { after extraction, the } \\
\text { extraction socket was filled } \\
\text { with hemocoagulase } \\
\text { solution (test site). After } 24 \\
\text { to } 48 \text { hours, extraction } \\
\text { procedure was carried out } \\
\text { on another site (control site) } \\
\text { and saline pressure pack } \\
\text { was placed } 23]\end{array}$ & $\begin{array}{l}\text { Bleeding stoppage time Test site: } \\
\text { Measurement of time from application of } \\
\text { hemocoagulase solution into the socket } \\
\text { until the complete stoppage of bleeding } \\
\text { was calculated using a stopwatch. } \\
\text { Control site: Saline pressure pack was } \\
\text { given to achieve hemostasis at this site } \\
\text { and the time taken for hemostasis was } \\
\text { calculated. Swelling reference points: } \\
\text { Lateral corner of the eye to the angle of } \\
\text { the mandible and tragus of the ear to the } \\
\text { corner of the mouth. Swelling was } \\
\text { measured on the first, second, third, } \\
\text { fourth, and fifth days [23] }\end{array}$ \\
\hline
\end{tabular}

TABLE 1: Characteristics of included studies: Methodologies

\begin{tabular}{|c|c|c|c|c|c|}
\hline $\begin{array}{l}\text { S. } \\
\text { NO }\end{array}$ & $\begin{array}{l}\text { AUTHOR } \\
\text { AND } \\
\text { JOURNAL }\end{array}$ & $\begin{array}{l}\text { STUDY } \\
\text { GROUPS }\end{array}$ & $\begin{array}{l}\text { STATISTICAL } \\
\text { ANALYSIS }\end{array}$ & RESULTS & INFERENCE \\
\hline 1 & $\begin{array}{l}\text { Aslam et al., } \\
\text { The Journal } \\
\text { of } \\
\text { Contemporary } \\
\text { Dental } \\
\text { Practice. } \\
2014 \text { [20] }\end{array}$ & $\begin{array}{l}1 . \\
\text { Hemocoagulase } \\
\text { solution } 2 . \\
\text { Placebo [20] }\end{array}$ & 't' test & $\begin{array}{l}\text { 1. Bleeding stoppage time: } \\
\text { Test site (hemocoagulase): } \\
1.3735 \pm 0.5218 \text { Control site } \\
\text { (saline pack): } 2.3275 \pm \\
0.84802 \text {. Pain at } 6 \text { hours: } \\
\text { Test site (hemocoagulase): } \\
20.0 \pm 32.163 \text { Control site } \\
\text { (saline pack): } 55.5 \pm 37.032 \\
\text { [20] }\end{array}$ & $\begin{array}{l}\text { Hemocoagulase group } \\
\text { achieved faster hemostasis } \\
\text { when compared to control } \\
\text { group. The results were highly } \\
\text { significant. Amount of pain on } \\
\text { site A (test) was found to be } \\
\text { less as compared to site B } \\
\text { (control). The result was } \\
\text { statistically significant [20]. }\end{array}$ \\
\hline
\end{tabular}




\section{Cureus}

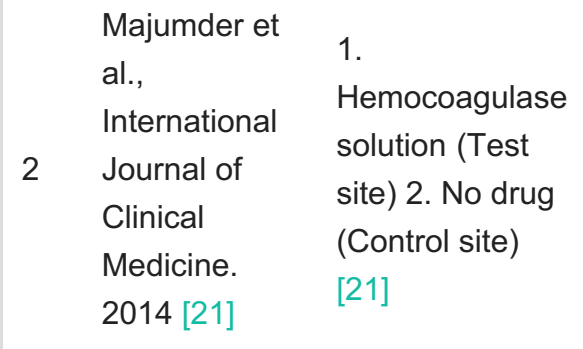

The student $\mathrm{t}-$ test for equality of means

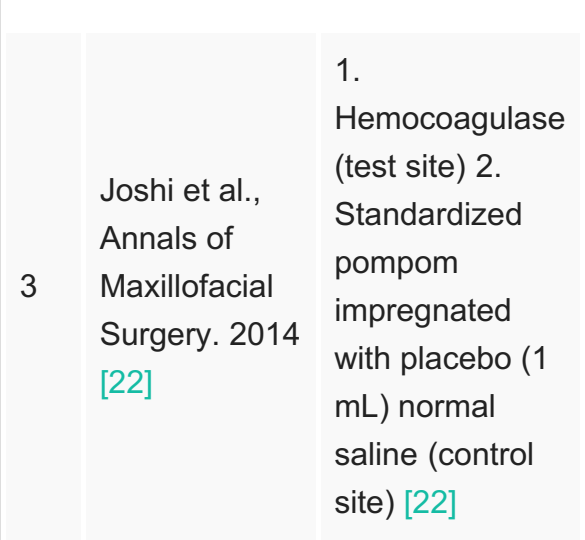

Solanki et al., International Journal of

4 Research in Medical Sciences. 2015 [23]

1. Hemocoagulase (test site) 2. Saline pressure pack (control site) [23]
1. Bleeding stoppage time:

Test site (hemocoagulase):

$1.3532 \pm 0.432$ Control site (saline pack): $2.2532 \pm 0.859$

2. Pain at six hours: Test site (hemocoagulase): $16.6 \pm$ 1.83 Control site (saline pack): $50.6 \pm 6.123$. Swelling: Test site (hemocoagulase): One hour: $26.23 \pm 6.1$ Two hours: 14.5 \pm 1.8 Three hours: $1.023 \pm .5$ Six hours: 0 Nine hours: 0 Control site (saline pack): One hour: $40.6 \pm 4.8$ Two hours: $32.6 \pm 4.6$ Three hours: $18.1 \pm 2.1$ Four hours: 0 Five hours: 0 [21]

Bleeding stoppage time: Test site (hemocoagulase):
$1.6732 \pm 0.5319$ Control site (saline pack): $3.0316 \pm 1.445$ [22]

1. Bleeding stoppage time: Test site (hemocoagulase): $1.5231+1.445$ Control site (saline pack): $3.311+1.316$

\section{Swelling:}

Unpaired ' $\mathrm{t}$ ' test

Swelling:

Time Test site $\begin{aligned} & \text { Control } \\ & \text { site }\end{aligned}$

$\begin{array}{lll}\text { First } & \text { NA } & 40.8 \pm \\ \text { day } & & 4.7\end{array}$

Second $\quad 50.16 \pm \quad 60.12 \pm$

day $\quad 2.13 \quad 3.126$

Third $\quad 30.061 \quad 36.126$

day $\pm 1.23 \pm 2.16$

Fourth $\quad 10.012 \quad 14.32 \pm$

day $\quad \pm 0.31 \quad 1.675$

$\begin{array}{lll}\text { Fifth } & \text { NA } & 4.069 \\ \text { day } & & \pm 0.653\end{array}$
Faster hemostasis was achieved at hemocoagulase site $(p=3.95)$. The result was statistically significant. Amount of pain on site A (test) was found to be less as compared to site $B$ (control). The result was statistically significant $(p=$ 0.01). Hemocoagulase site: 13 patients (26\%) had swelling after one hour and reduced to seven patients (14\%) by two hours. At control site, 20 patients (40\%) had swelling after one hour and reduced to 16 patients $(32 \%)$ by three hours $(p=0.02)$. The result was statistically significant [21].

The analysis revealed $p<$ 0.001 for bleeding stoppage time in the study group, which is highly significant [22].
Faster hemostasis was achieved on hemocoagulase site. In terms of swelling, there was not much differences on both the sites on the second and third postoperative days [23]. 


\section{Cureus}

\section{TABLE 2: Characteristics of included studies: Findings}

In all the studies, mean bleeding stoppage time was less in the hemocoagulase group when compared to the control group. The difference was statistically significant (Figure 2).

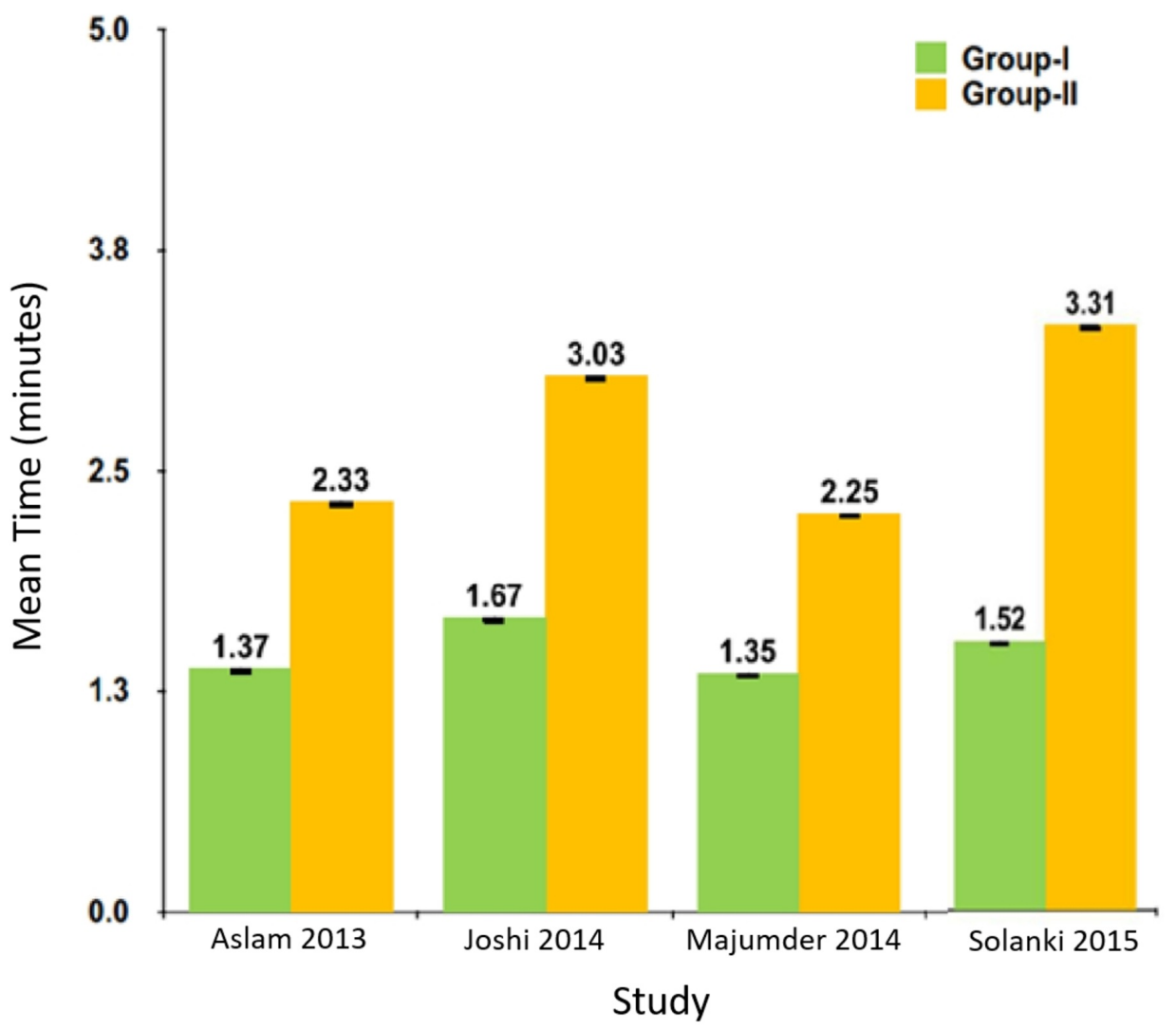

FIGURE 2: Mean bleeding stoppage time in included studies

Pain scores at the sixth hour were significantly less in the hemocoagulase groups (Figure 3). 


\section{Cureus}

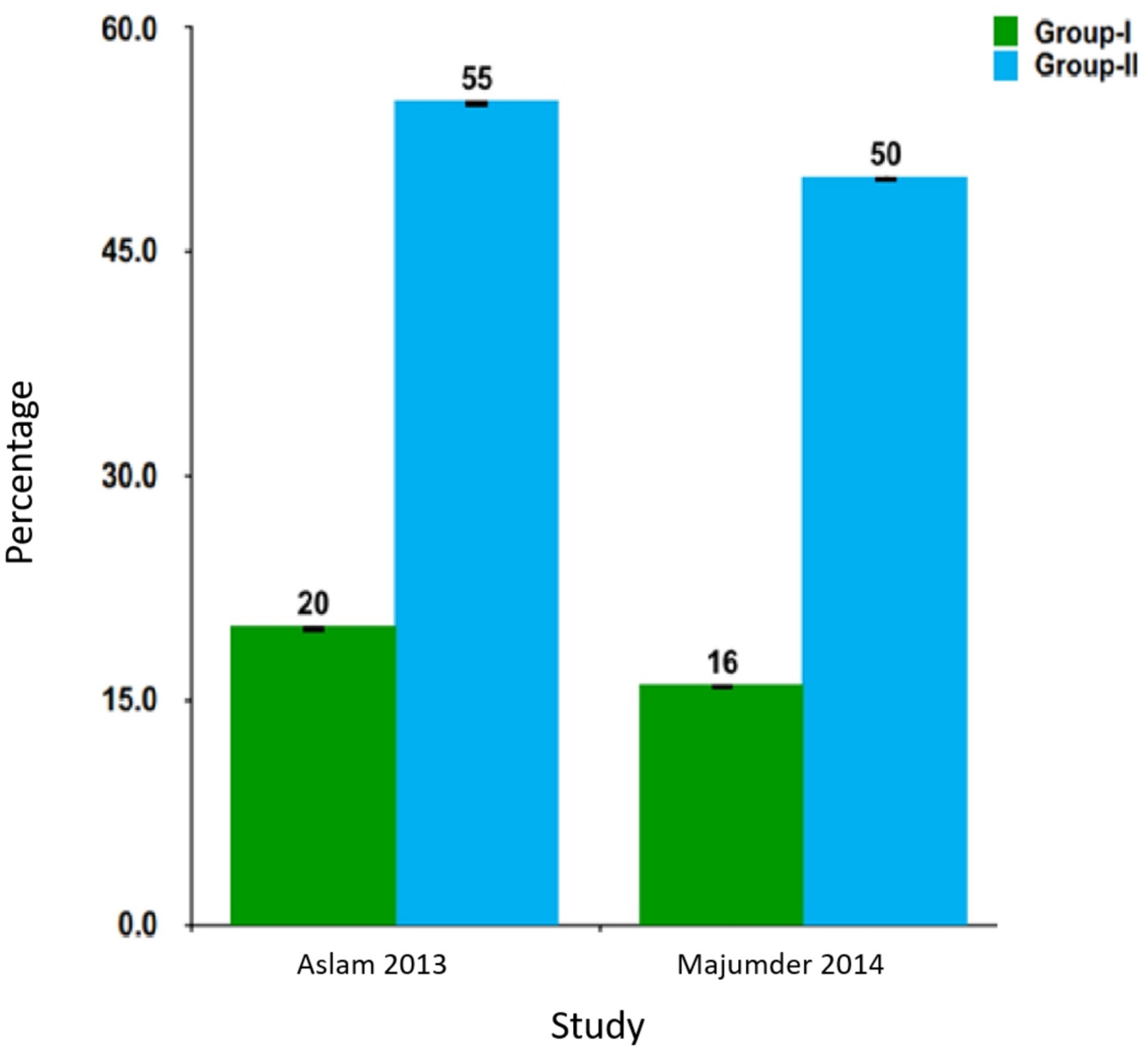

FIGURE 3: Pain scores in included studies

Swelling was more in placebo or control (saline pressure pack) sites than in hemocoagulase sites (Figure 4).

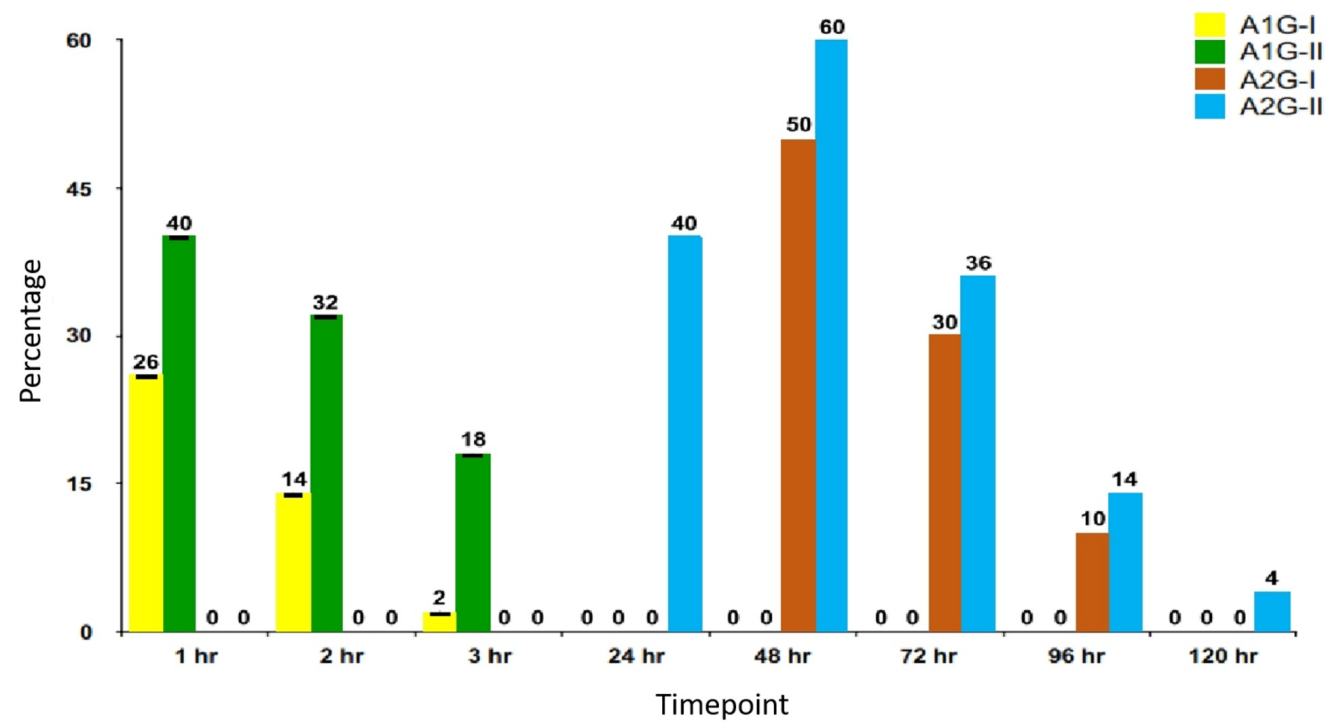

FIGURE 4: Prevalence of swellina in included studies 


\section{Cureus}

\section{Levels of evidence}

The levels of evidence for the reviewed studies are based on the Oxford Centre for Evidence-

Based Medicine (Table 3).

\begin{tabular}{|c|c|c|c|}
\hline S. No. & Author and Year & Study Design & Levels of Evidence \\
\hline 1 & Aslam et al., 2013 [20] & Case control & $3 b$ \\
\hline 2 & Majumdar et al., 2014 [21] & Prospective study & $2 \mathrm{~b}$ \\
\hline 3 & Joshi et al., 2014 [22] & Randomized controlled trial & 1 \\
\hline 4 & Solanki et al., 2015 [23] & Randomized controlled trial & 1 \\
\hline
\end{tabular}

\section{TABLE 3: Levels of evidence in included studies}

\section{Risk of bias}

The four main methodological studies were assessed for quality, and the included studies showed low to moderate risk of bias (Table 4).

\begin{tabular}{|c|c|c|c|c|c|}
\hline Study & Randomization & $\begin{array}{l}\text { Allocation } \\
\text { Concealed }\end{array}$ & $\begin{array}{l}\text { Assessor } \\
\text { Blinding }\end{array}$ & $\begin{array}{l}\text { Dropouts } \\
\text { Described }\end{array}$ & $\begin{array}{l}\text { Risk of } \\
\text { Bias }\end{array}$ \\
\hline Aslam et al., 2013 [20] & No & Yes & Yes & None & Moderate \\
\hline $\begin{array}{l}\text { Majumder et al., } 2014 \\
\text { [21] }\end{array}$ & No & Yes & Yes & None & Moderate \\
\hline Joshi et al., 2014 [22] & Yes & Yes & Yes & None & Low \\
\hline $\begin{array}{l}\text { Solanki, et al., } 2015 \\
\text { [23] }\end{array}$ & Yes & Yes & Yes & None & Low \\
\hline
\end{tabular}

TABLE 4: Risk of bias in included studies

\section{Benefits of hemocoagulase as a topical hemostatic agent}

Extraction of teeth is a common procedure in oral and maxillofacial surgery. Because the region of surgery is mostly composed of loose connective tissue that contains blood and lymph vessels, a series of functional and structural alteration is expected after extraction, mostly expressed as pain, prolongation of bleeding stoppage time, and swelling [13-14]. Hemocoagulase is a fractional isolate of poisonous Bothrops jararaca or Bothrops atrox and is an enzyme complex, with coagulative and anti-hemorrhagic properties [15-16]. Being a topical form, it also acts fast and is atoxic. Hemocoagulase has enzymatic actions similar to 
thromboplastin and thrombin, and thereby promotes rapid blood coagulation and wound healing [10].

Many studies have evaluated the healing mechanism of the extraction socket wound and the physiological changes that occur at the cellular level immediately after extraction [17-19]. There have been studies that have evaluated the role of hemocoagulase in reducing postoperative bleeding stoppage time in patients requiring extraction of teeth. Other parameters such as postoperative pain, swelling, wound healing, and infection rates were also evaluated.

Aslam et al. [20] conducted a study on 20 subjects to evaluate the efficacy of local application of hemocoagulase solution as compared to a placebo in wound healing following dental extraction. Bleeding stoppage time was recorded using a stopwatch to record the time from placement of solution until the complete formation of the clot. The differences between the hemocoagulase site and control site were significant. Pain was also evaluated at the sixth hour, and the amount of pain in the hemocoagulase group was less compared to the placebo group, and the results were statistically significant. The authors concluded that the topical hemocoagulase solution could be used as a hemostatic agent and promoter of wound healing in oral surgery.

Majumder et al. [21] evaluated the efficacy of topical hemocoagulase on 50 surgical sites in 25 patients who underwent simple extractions. Parameters such as bleeding stoppage time, pain, and swelling were measured. Time taken for hemostasis was calculated using a stopwatch. Facial swelling was recorded using measurements between the lateral corner of the eye to the angle of mandible and tragus of the ear to the corner of the mouth. Postoperatively, one information chart in the form of a visual analogue scale was given to each patient to evaluate pain. A significant difference was found in bleeding stoppage time, postoperative pain, and swelling between the test (hemocoagulase) and control (no drug) group. The authors concluded that use of hemocoagulase solution after extractions not only provides faster hemostasis but also enhances healing by rapid formation of healthy tissue with less chance of infection. Based on these results, it was suggested that further studies were required to prove the use of hemocoagulase in hemophilic patients.

Joshi et al. [22] compared bleeding stoppage time between the test (hemocoagulase) and the control (pompom impregnated with placebo [1 mL normal saline]) groups after symmetrical bilateral orthodontic extractions. A statistically significant difference was present between the test and the control groups. The authors concluded that hemocoagulase holds good prospects in managing postextraction bleeding in cardiac patients on aspirin without stopping aspirin before extraction. Its topical use provides faster hemostasis in patients undergoing dental extraction without any systemic or local adverse effect.

In a study by Solanki et al. [23], the researchers compared bleeding stoppage time, pain at the sixth hour, and swelling between the test (hemocoagulase) and control (saline pressure pack) groups after undergoing extractions. There were statistically significant differences between these groups on evaluation. The authors concluded that application of hemocoagulase to extraction socket will achieve faster hemostasis, reduce pain and swelling, and help in wound healing by rapid formation of healthy tissue. It also has the advantage of reducing the amount of infection in the extraction sockets.

Shenoy et al. [24] evaluated the effects of topical hemocoagulase on intra-oral extraction sockets as well as the impact on the healing process. In this study design, topical hemocoagulase was placed in one site while the other site did not receive anything. Clinical evaluation was done on the following postoperative days seven, 14, and 21 for all patients. 
Biopsies were done on a random basis either on day seven or 14 for cases as well as controls. A clinical and histopathological score was developed and wound healing was assessed. The clinical score did not show any statistical significance. However, the histopathology score had an increased incidence of osteoid formation in the hemocoagulase group on day 14 . The authors concluded that the application of hemocoagulase might improve and accelerate the process of wound healing in an extraction socket. This study was not included in the systematic review, as no comparable data with the previous studies were present.

From these studies, a single postoperative hemocoagulase application has been shown to reduce postoperative pain and swelling after dental extractions. Rapid hemostasis with the uneventful healing of extraction wounds with the use of hemocoagulase was observed in all these studies, and they emphasize that hemocoagulase plays an important role as a promoter of wound healing [20-24].

\section{Conclusions}

Based on the clinical evidence, topical hemocoagulase is an effective hemostatic agent after dental extractions. It also reduces pain and swelling and promotes wound healing by rapid formation of healthy tissue. Further large-scale clinical trials are necessary to explore additional applications of topical hemocoagulase solution in the field of oral and maxillofacial surgery.

\section{Additional Information \\ Disclosures}

Conflicts of interest: In compliance with the ICMJE uniform disclosure form, all authors declare the following: Payment/services info: All authors have declared that no financial support was received from any organization for the submitted work. Financial relationships: All authors have declared that they have no financial relationships at present or within the previous three years with any organizations that might have an interest in the submitted work. Other relationships: All authors have declared that there are no other relationships or activities that could appear to have influenced the submitted work.

\section{References}

1. Kamoh A, Swantek J: Hemostasis in oral surgery. Dent Clin North Am. 2012, 56:17-23. 10.1016/j.cden.2011.06.004

2. Kumar V, Abbas AK, Fausto N, Aster JC: Tissue renewal, regeneration and repair. In Robbins and Cotran Pathologic Basis of Disease. Saunders Elsevier, Philadelphia; 2010. 79-110.

3. Sumanth KN, Prashanti E, Aggarwal H, et al.: Interventions for treating postextraction bleeding. Cochrane Database Syst Rev. 2016, 10:011930. 10.1002/14651858.CD011930.pub2

4. Mingarro-de-León A, Chaveli-López B, Gavaldá-Esteve C: Dental management of patients receiving anticoagulant and/or antiplatelet treatment. J Clin Exp Dent. 2014, 6:155-161. $10.4317 /$ jced. 51215

5. Pippi R, Santoro M, Cafolla A: The effectiveness of a new method using an extra-alveolar hemostatic agent after dental extractions in older patients on oral anticoagulation treatment: an intrapatient study. Oral Surg Oral Med Oral Pathol Oral Radiol. 2015, 120:15-21. 10.1016/j.0000.2015.02.482

6. Ogle OE, Swantek J, Kamoh A: Hemostatic agents. Dent Clin North Am. 2011, 55:433-9. 10.1016/j.cden.2011.02.005

7. Schreiber MA, Neveleff DJ: Achieving hemostasis with topical hemostats: Making clinically and economically appropriate decisions in the surgical and trauma settings. AORN J. 2011, 94:1-20. 10.1016/j.aorn.2011.09.018

8. Al-Belasy FA, Amer MZ: Hemostatic effect of n-butyl-2-cyanoacrylate (histoacryl) glue in warfarin-treated patients undergoing oral surgery. J Oral Maxillofac Surg. 2003, 31:1405-9. 
10.1016/j.joms.2002.12.001

9. Nooh N, Abdullah WA, Grawish ME, et al.: The effects of surgical and bone wax hemostatic agents on bone healing: An experimental study. Indian J Orthop. 2014, 48:319-325. 10.4103/0019-5413.129451

10. Kumar S: Local hemostatic agents in the management of bleeding in oral surgery . Asian J Pharm Clin Res. 2016, 9:35-41.

11. Lu Q, Clemetson JM, Clemetson KJ: Snake venoms and hemostasis. J Thromb Haemost. 2005, 3:1791-9. 10.1111/j.1538-7836.2005.01358.x

12. Castro HC, Zingali RB, Albuquerque MG, Pujol-Luz M, Rodrigues CR: Snake venom thrombinlike enzymes: from reptilase to now. Cell Mol Life Sci. 2004, 61:843-56. 10.1007/s00018-0033325-z

13. Steiner GG, Francis W, Burrell R, et al.: The healing socket and socket regeneration. Compend Contin Educ Dent. 2008, 29:114-6.

14. Sultana J, Molla MR, Kamal M, et al.: Histological differences in wound healing in maxillofacial region in patients with or without risk factors. Bangladesh J Pathol. 2009, 24:38. 10.3329/bjpath.v24i1.2874

15. Stocker K, Barlow GH: The coagulant enzyme from Bothrops atrox venom (batroxobin) . Methods Enzymol. 1976, 45:214-23. 10.1016/S0076-6879(76)45021-8

16. Shenoy AK, Ramesh KV, Chowta MN, et al.: Effects of botropase on clotting factors in healthy human volunteers. Perspect Clin Res. 2014, 5:71-4. 10.4103/2229-3485.128024

17. Trombelli L, Farina R, Marzola A, et al.: Modeling and remodeling of human extraction sockets. J Clin Periodontol. 2008, 35:630-9. 10.1111/j.1600-051X.2008.01246.x

18. Boyne PJ: Osseous repair of the postextraction alveolus in man. Oral Surg Oral Med Oral Pathol Oral Radiol. 1966, 21:805-13. 10.1016/0030-4220(66)90104-6

19. Devlin H, Sloan P: Early bone healing events in the human extraction socket. Int J Oral Maxillofac Surg. 2002, 31:641-5. 10.1054/ijom.2002.0292

20. Aslam S, Francis PG, Rao BH, et al.: A double blind study on the efficacy of local application of hemocoagulase solution in wound healing. J Contemp Dent Pract. 2013, 14:394-400.

10.5005/jp-journals-10024-1334

21. Majumder K, Shalender S, Rao JK, et al.: Efficacy of haemocoagulase as a topical haemostatic agent after minor oral surgical procedures: A prospective study. Int J Clin Med. 2014, 5:875883. 10.4236/ijcm.2014.514117

22. Joshi SA, Gadre KS, Halli R, Shandilya R: Topical use of Hemocoagulase (Reptilase): A simple and effective way of managing post-extraction bleeding. Ann Maxillofac Surg. 2014, 4:119. 10.4103/2231-0746.133082

23. Solanki DA, Modha ND: Role of hemo-coagulase as a local haemostatic agent after extraction of tooth. Int J Res Med. 2015, 4:14-7.

24. Shenoy V, Baliga M, Mahajan S, et al.: The effects of topical hemocoagulase solution on the healing process of post-extraction wounds: a split mouth design. J Oral Maxillofac Surg. 2015, 14:586-93. 10.1007/s12663-014-0700-2 